Nat. Hazards Earth Syst. Sci. Discuss., doi:10.5194/nhess-2016-78, 2016

Manuscript under review for journal Nat. Hazards Earth Syst. Sci.

Published: 24 March 2016

(c) Author(s) 2016. CC-BY 3.0 License.

(c) (i)

\title{
Maintenance and risk management of rockfall protection net fences through numerical study of deteriorations
}

\author{
Andrea Luciani ${ }^{1}$, Monica Barbero ${ }^{2}$, Daniele Martinelli ${ }^{1}$, Daniele Peila ${ }^{1}$ \\ ${ }^{1}$ Department of Environment, Land and Infrastructure Engineering, Politecnico di Torino, Turin, 10129, Italy \\ $5 \quad$ Department of Structural, Geotechnical and Building Engineering, Politecnico di Torino, Turin, 10129, Italy \\ Correspondence to: A. Luciani (andrea.luciani@polito.it)
}

\begin{abstract}
Rockfall protection net fences are key protection systems in mountainous areas worldwide to ensure the safety of infrastructures, roads and urban areas against rockfall. Management of the maintenance of rockfall protection net fences is

10 fundamental for public administrations in order to guarantee risk mitigation. This paper deals with the assessment of the installation problems and deterioration of rockfall protection net fences, using numerical modelling in order to evaluate the influence of these issues on their behaviour. A percentage of the residual efficiency is assessed as a useful tool for risk analysis and maintenance planning.
\end{abstract}

15 Keywords: rockfall protection net fence, rockfall, explicit numerical modelling, deterioration, residual risk, maintenance.

\section{Introduction}

Rockfall protection net fences play an essential role in ensuring the safety of infrastructure, roads and residential areas against rockfall. They are widely used in mountainous environments to reduce rockfall risk within acceptable values. Since the installation of these protection devices requires important investments, procedures have been developed to quantitatively evaluate risk reduction performed by a device and to compare it with other technical solutions (Budetta 2004, Corominas et al. 2005, Peila and Guardini 2008, Mignelli et al. 2012). Moreover, the presence of protection devices on the slope has to be considered in the analysis and the efficacy of the already-installed works has to be evaluated, in order to do not overestimate the effect of these works. These procedures allow to perform an effective risk assessment (Budetta and Nappi, 2013, Mignelli et al., 2014, Budetta et al. 2015).

25 Therefore, it is important to take into account installation and maintenance issues of the rockfall protection net fences aiming to evaluate how these issues influence efficiency of the works and consequently risk mitigation. Effectively, public administrations are interested in this assessment in order to know the period that the investment in these devices ensures the risk mitigation. This evaluation allows them to schedule an appropriate maintenance management, taking into account the available resources.

30 Despite the highlighted relevance of the influence of the deteriorations and the installation problems on the behaviour and efficiency of rockfall protection net fences, there is a clear lack of data in technical literature on this topic. More critically, 
Nat. Hazards Earth Syst. Sci. Discuss., doi:10.5194/nhess-2016-78, 2016

Manuscript under review for journal Nat. Hazards Earth Syst. Sci.

Published: 24 March 2016

(c) Author(s) 2016. CC-BY 3.0 License.

there is currently no efficient predictive method that could be used to estimate the performance of a deteriorate rockfall protection fence. Moreover, there is great difference in the technical recommendations for the maintenance provided by producers: for rockfall protection net fences already installed, the maintenance manual is frequently absent, whereas for the newest works detailed technical user manuals are available, as required by ETAG 027 standards.

5 This paper proposes a method to quantitatively evaluate the influence of these issues on a rockfall protection net fence. The behaviour of these works was tackled both by full scale tests (Duffy and Hoon, 1996; Peila et al., 1995, 1998; Gottardi and Govoni, 2010; Trad et al., 2011; Buzzi et al., 2013), especially after the development in Europe of the ETAG 027 standards (Peila and Baratono, 2008; Peila and Ronco, 2009), by pseudo-static analyses (Peila et al., 1998; Cantarelli and Giani, 2006) and by numerical modelling (Nicot et al., 2001; Cazzani et al., 2002; Grassl et al., 2002; Volkwein, 2005; Peila

10 et al., 2006; Gentilini et al., 2012, 2013; Spadari et al., 2012; Escallón and Wendeler, 2013; Escallón et al., 2014; Moon et al., 2014).

Even though numerical modelling was used to study nominal effectiveness of non-tested net fences (Gottardi et al. 2011), it yet has not been used to analyse deteriorated rockfall net fences.

This paper studies influence of deteriorations and installation problems on the efficiency of rockfall protection net fences by

15 using numerical modelling. The assessment of the possible deteriorations and installation problems was performed based on an analysis of data obtained during a site survey in Alpine area in the North of Italy.

An impact test according to the ETAG 027 standards is numerically simulated. This allow to determinate the possible reduction of efficiency of the kits and compare the behaviour of the deteriorated and not deteriorated rockfall protection net fences. The simulation is performed with a FEM model of a rockfall protection net fence of nominal energy of $3000 \mathrm{~kJ}$. The

20 model is assessed using the results of experiments on full-scale prototypes whose data were obtained from Gottardi and Govoni (2010). Impact analyses are then carried out onto deteriorated models of the rockfall protection net fence to investigate their modified response in dynamic conditions.

The paper investigates the deterioration of rockfall protection net fences, in order to focus the importance of maintenance and design management for public administrations and to identify a useful tool for decision makers.

\section{Numerical model of the net fence}

In order to evaluate the impact of deteriorations on the behaviour of net fences, a numerical model was developed using the software ABAQUS/Explicit 6.13. This software has an explicit finite element formulation allowing to simulate non-linear dynamic events such as the impact of a block on a net fence.

The studied net fence is a commercial product with a Maximum Energy Level (MEL) of $3000 \mathrm{~kJ}$. This net fence was tested 30 in real scale by Gottardi and Govoni (2010). The data reported by Gottardi and Govoni (2010) were used for back analysis. The support structure of this net fence has four HEA200 steel posts, $5 \mathrm{~m}$ high, restrained at the base by cylindrical hinges allowing rotation in the upstream-downstream direction. The interception structure is made of a principal steel ring net; each 
Nat. Hazards Earth Syst. Sci. Discuss., doi:10.5194/nhess-2016-78, 2016

Manuscript under review for journal Nat. Hazards Earth Syst. Sci.

Published: 24 March 2016

(c) Author(s) 2016. CC-BY 3.0 License.

$350 \mathrm{~mm}$ ring is connected to six nearest rings. The connection structure comprises two longitudinal upper cables and two longitudinal lower cables, eight upstream cables and four lateral cables. Each cable has a diameter of $20 \mathrm{~mm}$. The longitudinal cables are free to slide on the posts in the longitudinal direction. The net fence is provided with tubular energy dissipating devices, one on each upstream cable and three on each longitudinal cable. Figure 1 shows a photo of the net 5 fence.

In the numerical simulation performed in this paper, the support structure was modelled with 3D-2node beam elements, with the cross section of the HEA200. These elements had linear elastic behaviour with Young's modulus of $210 \mathrm{GPa}$.

The cables, the energy dissipating devices and the net were modelled with 3D-2node truss elements that cannot withstand flexural stresses.

10 The material assigned to the cables had elasto-plastic behaviour with a Young's modulus of $150 \mathrm{GPa}$ in the elastic part of the curve and of $5 \mathrm{GPa}$ in the plastic one. The yield strain was set at 0.001 and the ultimate strain at 0.006 , wich corresponds to an ultimate stress of $1770 \mathrm{MPa}$.

The behaviour of the cable connected to the energy dissipating device is complex. At first the cable withstands the force until the activation force of the dissipating device is reached (at about $45 \mathrm{kN}$ ). Then, the deformation of the material composing

15 the device starts, and the constitutive relationship is governed by this phenomenon. Once the maximum displacement is reached, the system assumes again the cable behaviour.

Thus, tri-linear behaviour was assigned to the material of the energy dissipating devices. The first part had a Young's modulus of $63 \mathrm{GPa}$, the second one a Young's modulus of $1.4 \mathrm{GPa}$ and the last part had same behaviour of the cables, with Young's modulus of $150 \mathrm{GPa}$ and ultimate stress of $1770 \mathrm{MPa}$.

20 Simulation of the ring net is complex, due to the high number of interactions between the rings and the need to simulate deformations of all the rings. Therefore, in line with Nicot et al. (2001), an equivalent hexagonal net was modelled, with hexagon sides of $350 \mathrm{~mm}$. The material assigned to the elements composing the equivalent net had tri-linear behaviour, described by three different Young's moduli. The Young's modulus of the first part was of $170 \mathrm{GPa}$, till a strain of 0.001 was reached. The Young's modulus of the second part was of 4GPa, till a strain of 0.25 , and the Young's modulus of the

25 final part was of $170 \mathrm{GPa}$. This constitutive behaviour was assessed numerically simulating the real scale tests reported by Gentilini et al. (2013).

The block impacting the net was simulated as a polyhedral non-deformable element, with the geometry imposed by ETAG 027 standards. In accordance with this regulation, the block had velocity of $25 \mathrm{~m} / \mathrm{s}$ when it firstly touched the net in the centre of the central panel.

30 In the numerical model, the posts were restrained at the base by a cylindrical hinge allowing rotation on the longitudinal axis. Spherical hinges simulated anchorages of the cables to the ground and to the top of the posts. The longitudinal cables were free to slide on the top and on the basis of the posts in the longitudinal direction but were constrained in the other directions. In the model, the net was not allowed to slide on the longitudinal cables, differently to what happen in the real net fence. 
Nat. Hazards Earth Syst. Sci. Discuss., doi:10.5194/nhess-2016-78, 2016

Manuscript under review for journal Nat. Hazards Earth Syst. Sci.

Published: 24 March 2016

(c) Author(s) 2016. CC-BY 3.0 License.
Natural Hazards

and Earth System

Sciences

Discussions

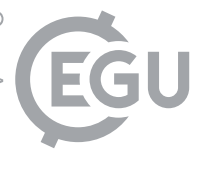

This simplification was necessary in order to reduce computational effort of the simulation. Figure 2 - Drawing of the rockfall protection net fence modelledillustrates the general sketch of the model of the rockfall protection net fence.

MEL and SEL tests were simulated on the numerical model of the net fence and the results of these simulations were compared to those of the real scale MEL and SEL tests reported by Gottardi and Govoni (2010). As can be seen from Table

5 1, the numerical model well reproduced the results of the real scale tests. The parameters used in the comparison were assumed as defined in the ETAG 027 standards. In the simulation, the breaking time was evaluated as the first time the velocity of the block zeroed and the maximum elongation was the maximum distance between the initial position of the net and the position of the net at the breaking time measured parallel to the slope. The final elongation was the same distance evaluated at the end of the test, assumed at $6 \mathrm{~s}$ from the first contact of the block with the net. The residual height was the

10 minimum distance between the lower and the upper longitudinal cables at the end of the simulation.

Figure 3 shows the model deformation during the MEL test at six different instants: particularly $\mathrm{t}=0 \mathrm{~s}$ is the first contact of the block with the net, $\mathrm{t}=0.36 \mathrm{~s}$ is the breaking time and $\mathrm{t}=6.00 \mathrm{~s}$ is the test end time.

\section{Numerical simulation of deteriorations}

In order to evaluate the influence of the problems detected in the site survey, the developed numerical model was modified

15 to reproduce six different conditions. On these modified models MEL impact tests were performed at different energy levels. The aim was to identify the maximum energy the modified net fence can withstand without failure of one of the principal elements.

Failure of cables and energy dissipating devices was established when one of these elements reached a plastic strain bigger than that correlated to the ultimate stress. Since the model uses an equivalent net, the ultimate stress of the net was unknown.

20 Therefore, it was considered failed if at least one of the elements composing the net reached a plastic strain bigger than the maximum recorded during the original model MEL simulation.

The residual efficiency $\left(r_{e f}\right)$ of the net fence was evaluated as

$$
r_{e f}=\frac{E_{M W}}{E_{\text {nom }}} \quad(\%)
$$

where $E_{M W}$ is the maximum energy the net fence can withstand and $E_{n o m}$ the nominal energy of the net fence according to

25 the classification of ETAG 027 . This value can be integrated in the rockfall risk analysis in order to take into account in this process the deterioration and installation conditions of the net fence.

According to Peila and Guardini (2008), the effect of a rockfall protection device on the rockfall risk may be assessed as

$$
N_{r}^{\prime}=(1-C) \cdot N_{r}
$$

where $N_{r}$ is the number of blocks reaching the road without the protection device, $N^{\prime}{ }_{r}$ those reaching the road with the

30 device and $C$ is the catching capacity of the device. The catching capacity is the percentage of blocks that the device can 
Nat. Hazards Earth Syst. Sci. Discuss., doi:10.5194/nhess-2016-78, 2016

Manuscript under review for journal Nat. Hazards Earth Syst. Sci.

Published: 24 March 2016

(c) Author(s) 2016. CC-BY 3.0 License.

catch, and it takes into account the geometry, the position and the nominal energy of the device. The residual efficiency can easily be take into account modifying the previous equation as follow

$$
N_{r}^{\prime}=\left(1-C \cdot r_{e f}\right) \cdot N_{r}
$$

The six modified models represented four different problematic configurations recorded during the site survey.

5 Models from (a) to (d) reproduced the failure of connections made by rope clips of the upstream cables, due to installation not in accordance with regulations in force or to clip corrosion. These configurations were similar to wrong applications observed during the site survey. In these cases, one or two of the upstream cables were removed from the model in order to simulate that the connection was not working and thus the cable cannot withstand any stress.

Moreover, models (c) and (d) also reproduced the failure of one anchorage of the upstream cable. This was obtained

10 removing from the simulation the two cables restrained at that anchorage.

Model (e) reproduced the effect of short and horizontal upstream cables. The original model had oblique upstream cables of $7.7 \mathrm{~m}$ while in this model they were horizontal with a length of $5.7 \mathrm{~m}$. Model (f) reproduced the effect of very long upstream cables. The upstream cables of this model were $20.0 \mathrm{~m}$ long instead of $7.7 \mathrm{~m}$ of the original model. These configurations too are similar to some of the configurations observed during the site survey.

15 Figure 4 shows the geometry of the various models compared to that of the original model.

In models (a), (b) and (d) the modified net fence resisted the impact at $3000 \mathrm{~kJ}$ without failure of any element, while in model (c) the net failed at an impact of $3000 \mathrm{~kJ}$ and withstood an impact of $2900 \mathrm{~kJ}$. However, in these four models the maximum elongation of the net fence increased, up to the $20 \%$ in model (c) (Figure 5). This result is very important in terms of correct positioning of the net fence on the slope. This behaviour was due to the lack of constrains of the system. The residual efficiency for model (a), (b) and (d) was then of $100 \%$ and of $97 \%$ for model (c).

In model (e), the net, the lower longitudinal cables and the two energy dissipating devices of the upstream cables convergent to the central anchorage get to failure for an impact energy of $3000 \mathrm{~kJ}$. These failures were due to the higher stiffness of the net fence originated by the shorter upstream cables. The model withstood an energy of $2400 \mathrm{~kJ}$ with residual efficiency of $80 \%$.

25 In model (f), the longitudinal cables failed at an impact of $3000 \mathrm{~kJ}$. In this condition, the energy dissipating devices of the upstream cables were not activated. Since upstream cables were longer and thus their stiffness was smaller, they were less charged. Consequently, the energy coming from the impact concentrated on the other elements of the net fence and particularly on the longitudinal cables. The model withstood an impact at $2600 \mathrm{~kJ}$, with residual efficiency of $87 \%$.

Table 2 summarizes the results obtained from the six models in terms of maximum energy withstood and residual efficiency.

\section{Conclusions}

This study has analysed the influence of deteriorations on the behaviour of rockfall protection net fences and on the design procedure, based on the results of a site survey on many net fences in the North of Italy. This site survey pointed out that 
Nat. Hazards Earth Syst. Sci. Discuss., doi:10.5194/nhess-2016-78, 2016

Manuscript under review for journal Nat. Hazards Earth Syst. Sci.

Published: 24 March 2016

(c) Author(s) 2016. CC-BY 3.0 License.
Natural Hazards 응

and Earth System

Sciences

Discussions

(c) $\underset{\mathrm{BY}}{\mathrm{B}}$

many problems related to the rockfall protection net fences come from installation problems due to local geometry. The present study highlights how this aspect has to be taken into due account in the design stage.

The numerical simulation of rockfall protection net fences already proved to be a good tool for the study of these devices but, in this paper, the application was extended to evaluate the behaviour of rockfall protection net fences subjected to

5 damages. The purpose of this extension was to assess how these damages will affect the efficiency of products. Thus, six models of a commercial net fence were studied and the maximum energy these models could withstand was assessed, taking into account different geometrical and deterioration conditions. This permitted to define the residual efficiency of fences.

This residual efficacy may be included in rockfall risk analysis within the evaluation of the catching capacity of the net fence. In this way, the assessment of residual efficiency of a rockfall protection net fence becomes useful for local

10 administrations and decision makers in order to perform correct risk analyses. Effectively, the appraisal of the capacity of a device to reduce risk must take into account the state of degradation of the net fence. Moreover, this appraisal allows owners to plan eventual maintenance or refurbishment works and establish priority between different protection devices.

Furthermore, this paper highlights a specific procedure that can be used by designer and producer companies to assess the influence of different types of deteriorations and different types of products. This would permit to generalize the results and

15 establish general relations between deteriorations occurring to a rockfall protection net fence and the resulting loose of efficiency in risk mitigation.

Acknowledgments The authors would like to thank Regione Autonoma Valle d'Aosta for permission to publish the case history data and for financial support of the present research.

\section{References}

Budetta, P.: Assessment of rockfall risk along roads, Nat. Hazards Earth Syst. Sci., 4, 71-81, 2004.

Budetta, P., Nappi, M.: Comparison between qualitative rockfall risk rating systems for a road affected by high traffic intensity, Nat. Hazards Earth Syst. Sci., 13, 1643-1653, 2013.

Budetta, P., De Luca, C., Nappi, M.: Quantitative rockfall risk assessment for an important road by means of the rockfall risk 25 management (RO.MA.) method, Bull. Eng. Geol. Environ., 1-21, 2015.

Buzzi, O., Spadari, M., Giacomini, A., Fityus, S., Sloan, S. W.: Experimental testing of rockfall barriers designed for the low range of impact energy, Rock Mech. Rock Eng., 46, 701-712, 2013.

Cantarelli, G., Giani, G. P.: Analisi dei metodi di verifica dell'efficienza di reti di protezione contro la caduta massi. Rivista Italiana di Geotecnica, 40, 23-31, 2006.

30 Cazzani, A., Mongiovì, L., Frenez, T.: Dynamic finite element analysis of interceptive devices for falling rocks, Int. J. Rock Mech. Min., 39, 303-321, 2002. 
Nat. Hazards Earth Syst. Sci. Discuss., doi:10.5194/nhess-2016-78, 2016

Manuscript under review for journal Nat. Hazards Earth Syst. Sci.

Published: 24 March 2016

(C) Author(s) 2016. CC-BY 3.0 License.
Natural Hazards

and Earth System

Sciences

Discussions

(c) (i)

Corominas, J., Copons, R., Moya, J., Vilaplana, J. M., Altimir, J., Amigò, J.: Quantitative assessment of the residual risk in a rockfall protected area, Landslides, 2, 343-357, 2005.

Duffy, J. D., Hoon, W.: Fild tests and evaluation of HI-tech 50 and 70 foot-ton rockfall fence, Report No. CA/05-96-02, California Dept. of Trasportation, San Luis Obispo, Ca, 1996.

5 EOTA: Guideline for European Technical approval of falling rock protection kits (ETAG 027). February 2008, Brussels.

Escallón, J. P., Wendeler, C.: Numerical simulations of quasi-static and rockfall impact tests of ultra-high strength steel wire-ring nets using Abaqus/Explicit, in: 2013 SIMULIA Community conference, 2013.

Escallón, J. P., Wendeler, C., Chatzi, E., Bartelt, P.: Parameter identification of rockfall protection barrier components through an inverse formulation, Eng. Struct., 77, 1-16, 2014.

10 Gentilini, C., Govoni, L., de Miranda, S., Gottardi, G., Ubertini, F.: Three-dimensional numerical modelling of falling rock protection barriers, Computers and Geotechnics, 44, 58-72, 2012.

Gentilini, C., Gottardi, G., Govoni, L., Mentani, A., Ubertini, F.: Design of falling rock protection barriers using numerical models, Eng. Struct., 50, 96-106, 2013.

Gottardi, G., Govoni, L.: Full-scale modelling of falling rock protection barriers, Rock Mech. Rock Eng., 43, 261-274, 2010.

15 Gottardi, G., Govoni, L., Mentani, A., Ranali, M., Strada, C.: The effectiveness of protection systems toward rockfall risk mitigation, in: Proceedings of 3rd International Symposium on Geotechnical Safety and Risk (ISGSR2011), Munich, Germany, Vogt NB, Schuppener B. (eds), 157-164, 2011.

Grassl, H., Volkwein, A., Anderheggen, E., Ammann, W. J.: Steel-net rockfall protection - experimental and numerical simulation, in: Proceedings of 7th International Conference on Structures Under Shock and Impact, Montreal, Canada, May

$202002,143-153,2002$.

Mignelli, C., Lo Russo, S., Peila, D.: ROckfall risk MAnagement assessment: the RO.MA. approach, Nat. Hazards, 62, 1109-1123, 2012.

Mignelli, C., Peila, D., Lo Russo, S., Ratto, S. Broccolato, M.: Analysis of rockfall risk on mountainside roads: evaluation of the effect of protection devices, Nat. Hazards, 73, 25-35, 2014.

25 Moon, T., Oh, J., Mun, B.: Practical design of rockfall catchfence at urban area from a numerical analysis approach, Eng. Geol., 172, 41-56, 2014.

Nicot, F., Cambou, B., Mazzoleni, G.: Design of rockfall restraining nets from a discrete element modelling, Rock Mech. Rock Eng., 34, 99-118, 2001.

Peila, D., Baratono, P.: ETAG027: una grande innovazione nel settore delle opere di protezione contro la caduta massi,

30 Geoingegneria Ambientale e Mineraria, 125, 49-52, 2008.

Peila, D., Guardini, C.: Use of the event tree to assess the risk reduction obtained from rockfall protection devices, Nat. Hazard Earth Syst. Sci., 8, 1441-1450, 2008.

Peila, D., Ronco, C.: Technical Note: Design of rockfall net fences and the new ETAG 027 European guideline. Nat. Hazards Earth Syst. Sci., 9, 1291-1298, 2009. 
Nat. Hazards Earth Syst. Sci. Discuss., doi:10.5194/nhess-2016-78, 2016

Manuscript under review for journal Nat. Hazards Earth Syst. Sci.

Published: 24 March 2016

(c) Author(s) 2016. CC-BY 3.0 License.

(c) (1)

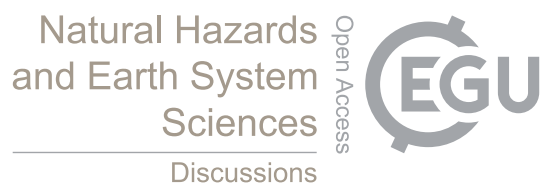

Peila, D., Pelizza, S., Sassudelli, F.: Prove in scala reale su barriere paramassi deformabili a rete, Geoingegneria Ambientale e Mineraria, 86, 147-153, 1995.

Peila, D., Pelizza, S., Sassudelli, F.: Evaluation of behaviour of rockfall restraining nets by full scale tests, Rock Mech. Rock Eng., 31, 1-24, 1998.

5 Peila, D., Oggeri, C., Baratono, P.: Barriere paramassi a rete. Interventi e dimensionamento, Geoingegneria Ambientale e Mineraria, Quaderni di studio e documentazione $\mathrm{n}^{\circ} 25$, Torino, 2006.

Spadari, M., Giacomini, A., Buzzi, O., Hambleton, J.P.: Prediction of the bullet effect for rockfall barriers: a scaling approach, Rock Mech. Rock Eng., 45, 131-144, 2012.

Trad, A., Limam, A., Bertrand, D., Robit, P.: Multi-scale analysis of an innovative flexible rockfall barrier, in: Rockfall

10 Engineering, Lambert, S., Nicot, F., Iohn Wiley \& Sons, New York, STE Ltd and J, 303-342, 2011.

Volkwein, A.: Numerical simulation of flexible rockfall protection systems, in: Proceedings of the International Conference on Computing in Civil Engineering, Cancun, Mexico, ASCE, 1285-95, 2005. 
Nat. Hazards Earth Syst. Sci. Discuss., doi:10.5194/nhess-2016-78, 2016

Manuscript under review for journal Nat. Hazards Earth Syst. Sci.

Published: 24 March 2016

(c) Author(s) 2016. CC-BY 3.0 License.
Natural Hazards and Earth System (c) (i)

\begin{tabular}{|c|c|c|c|c|}
\cline { 2 - 5 } \multicolumn{1}{c|}{} & \multicolumn{2}{c|}{ MEL Test } & \multicolumn{2}{c|}{ SEL Test } \\
\cline { 2 - 5 } \multicolumn{1}{c|}{} & Real scale test & $\begin{array}{c}\text { Numerical } \\
\text { model }\end{array}$ & Real scale test & $\begin{array}{c}\text { Numerical } \\
\text { model }\end{array}$ \\
\hline Breaking time $[\mathrm{s}]$ & 0.30 & 0.32 & 0.26 & 0.22 \\
\hline Maximum elongation $[\mathrm{m}]$ & 5.35 & 5.38 & 3.90 & 3.73 \\
\hline Final elongation $[\mathrm{m}]$ & 4.80 & 5.05 & 3.20 & 3.35 \\
\hline Residual height $[\mathrm{m}]$ & 3.55 & 3.34 & 3.95 & 3.71 \\
\hline
\end{tabular}

Table 1 - Comparison between the real scale test and the results of the numerical simulation.

\begin{tabular}{|c|l|c|c|}
\hline Model & \multicolumn{1}{|c|}{ Problem simulated } & $\begin{array}{c}\text { Maximum energy } \\
\text { withstood [kJ] }\end{array}$ & $\begin{array}{c}\text { Residual efficiency } \\
{[\%]}\end{array}$ \\
\hline a & Failure of one clip connection or of one upstream cable & 3000 & 100 \\
\hline b & Failure of one clip connection or of one upstream cable & 3000 & 100 \\
\hline c & $\begin{array}{l}\text { Failure of two clip connection or of two upstream cable or of } \\
\text { an anchorage }\end{array}$ & 2900 & 100 \\
\hline d & $\begin{array}{l}\text { Failure of two clip connection or of two upstream cable or of } \\
\text { an anchorage }\end{array}$ & 3000 & 80 \\
\hline e & Short and horizontal upstream cables & 2400 & 87 \\
\hline f & Long upstream cables & 2600 & 97 \\
\hline
\end{tabular}

Table 2 - Summary of the results of the numerical simulations 
Nat. Hazards Earth Syst. Sci. Discuss., doi:10.5194/nhess-2016-78, 2016 Manuscript under review for journal Nat. Hazards Earth Syst. Sci.

Published: 24 March 2016

(c) Author(s) 2016. CC-BY 3.0 License.

\section{Natural Hazards and Earth System Sciences \\ Discussions}
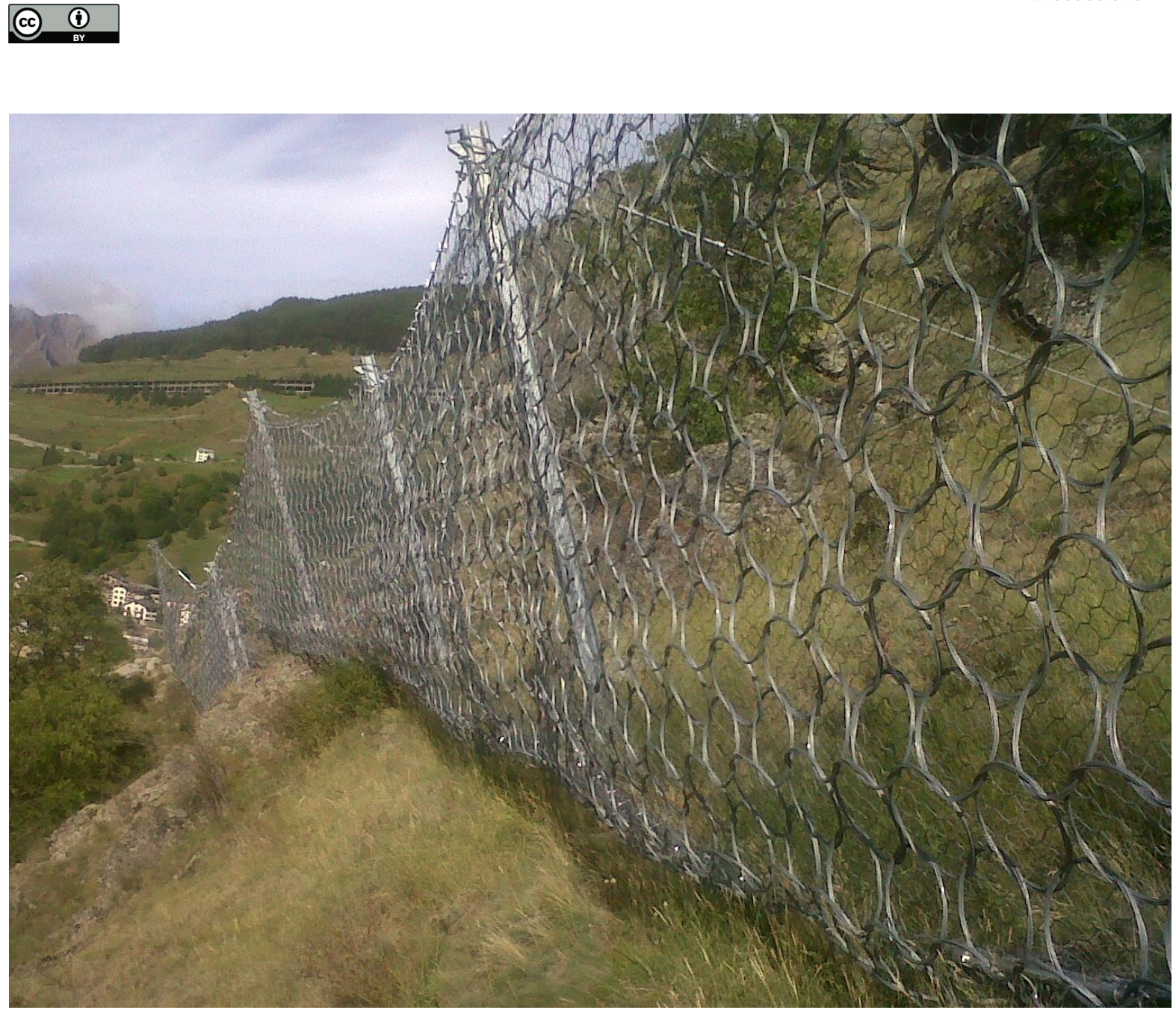

Figure 1 - Photo of the rockfall protection net fence studied

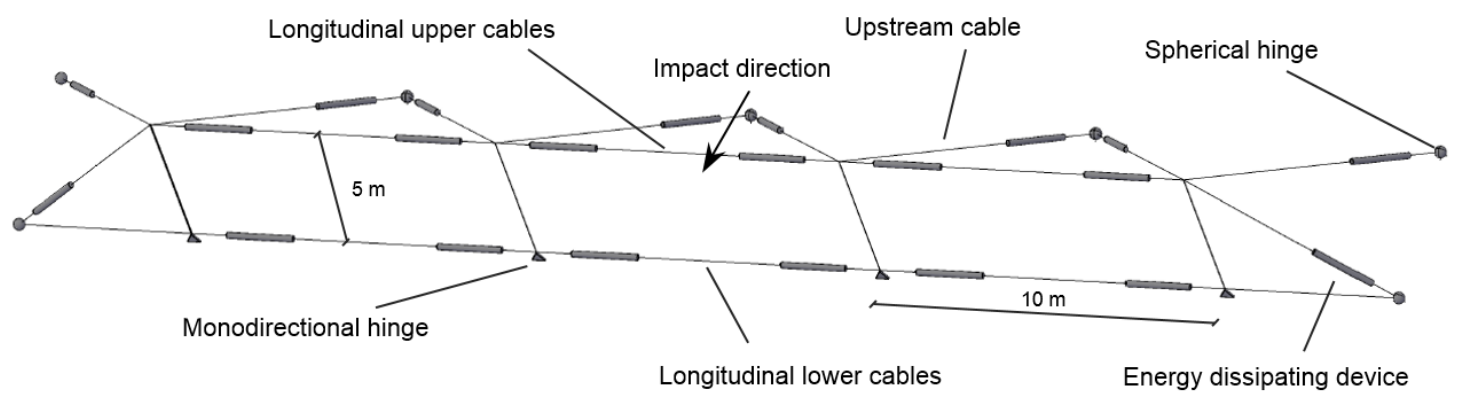

Figure 2 - Drawing of the rockfall protection net fence modelled 
Nat. Hazards Earth Syst. Sci. Discuss., doi:10.5194/nhess-2016-78, 2016

Manuscript under review for journal Nat. Hazards Earth Syst. Sci.

Published: 24 March 2016

(c) Author(s) 2016. CC-BY 3.0 License.

(c) (i)

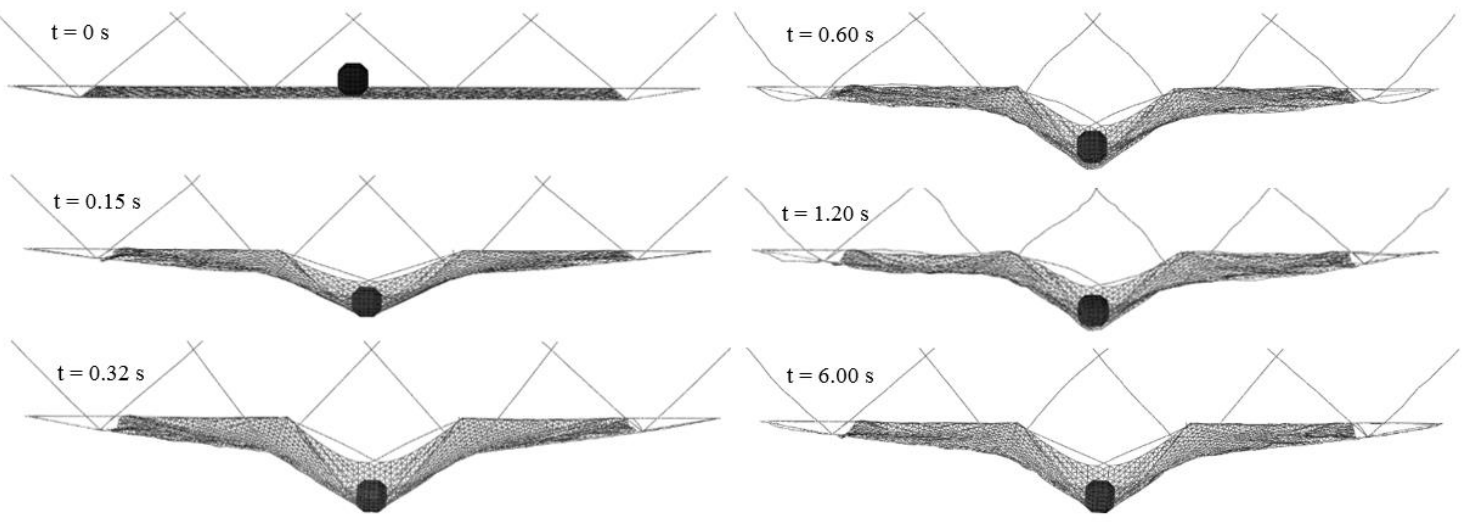

Figure 3 - Numerical modelled net fence during the MEL test

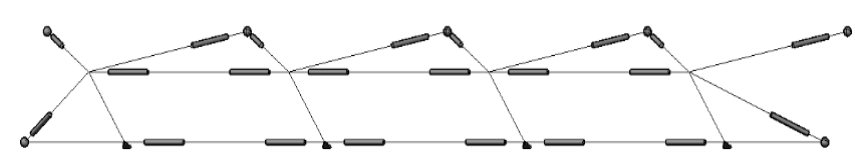

Original model front view
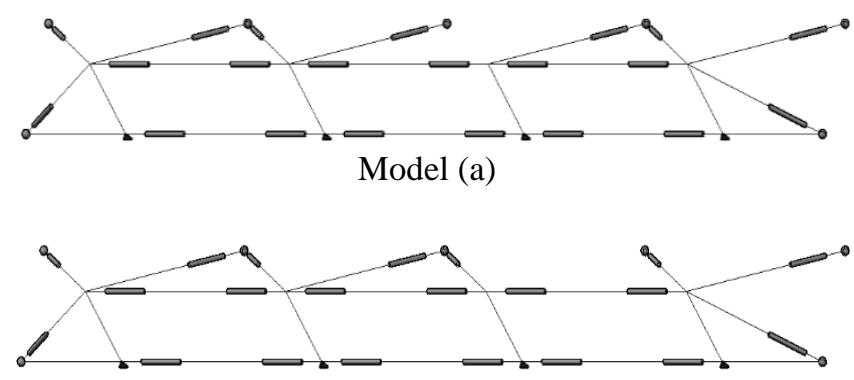

Model (b)
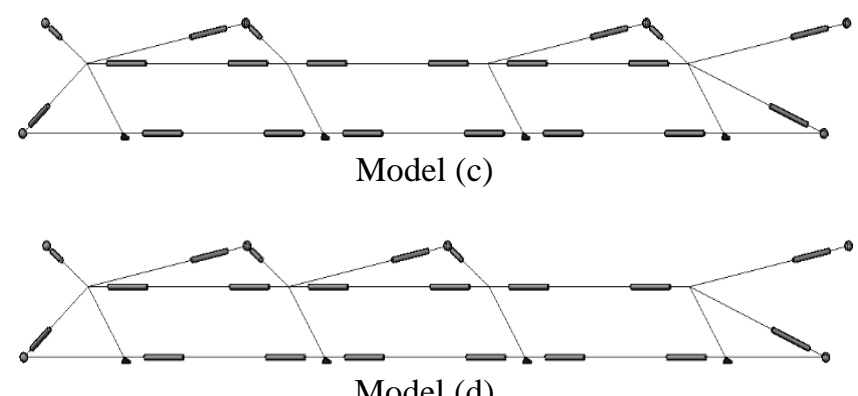

Model (d)

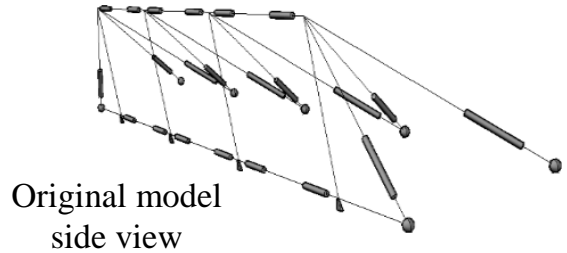

side view
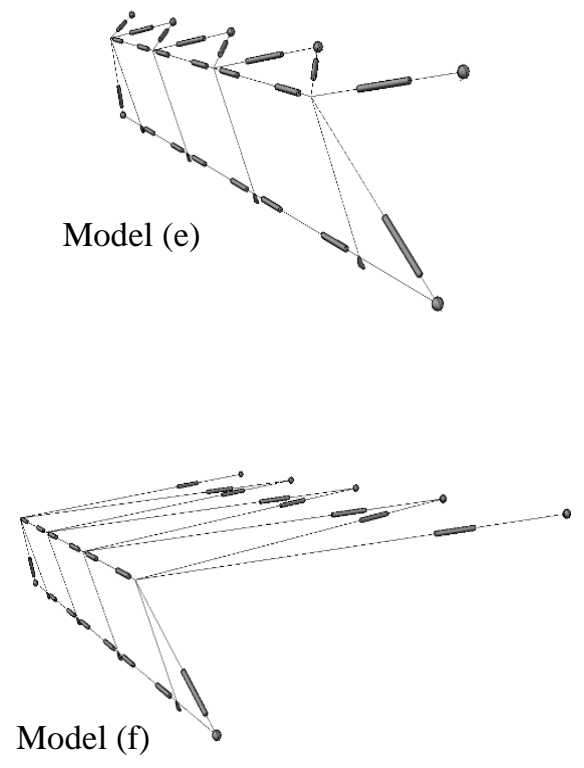

Figure 4 - Drawing of the original and modified models of the rockfall protection net fence 
Nat. Hazards Earth Syst. Sci. Discuss., doi:10.5194/nhess-2016-78, 2016

Manuscript under review for journal Nat. Hazards Earth Syst. Sci.

Published: 24 March 2016

(c) Author(s) 2016. CC-BY 3.0 License.

(c) (1)

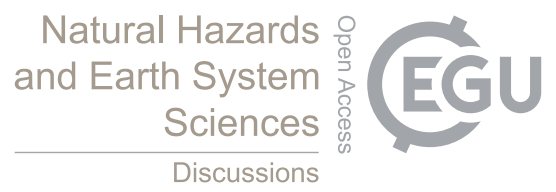

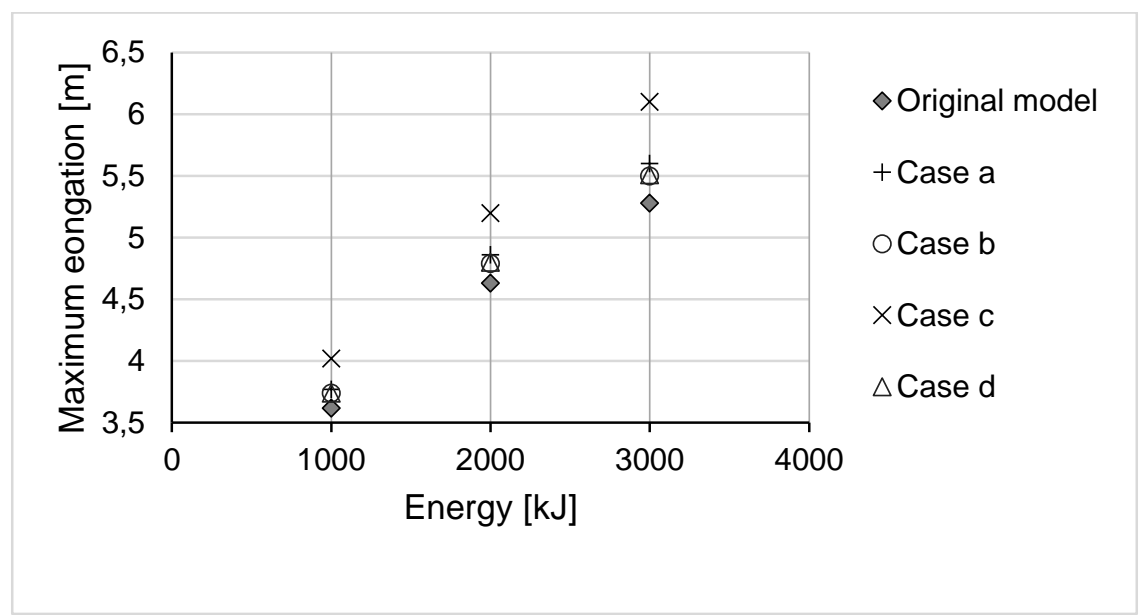

Figure 5 - Comparison of the maximum elongation of the original model and of models (a), (b), (c) and (d) 